\title{
ANALISIS FAKTOR - FAKTOR YANG MEMPENGARUHI TINGKAT PRODUKSI SELADA AIR (STUDI DESA WRINGIN ANOM KECAMATAN PONCOKUSUMO KABUPATEN MALANG)
}

\author{
Rif' atin Amalia, Idah Zuhroh, Syamsul Hadi \\ Program Studi Ekonomi Pembangunan, Fkaultas Eknomi dan Bisnis, Universitas Muhammadiyah \\ Malang, Jl.Raya Tlogomas No.246 Malang, Indonesia \\ * Corresponding author: fenynuri13@gmail.com
}

\begin{tabular}{|c|c|}
\hline Artikel Info & Abstract \\
\hline Article history: & This study aims to analyze the effect of land area, labor, \\
\hline Received 25 November 2019 & production facilities costs on the results of watercress \\
\hline Revised 5 December 2019 & production in Poncokumo District, Malang Regency in one \\
\hline Accepted 10 January 2020 & season. The data used is primary data, which obtained \\
\hline Available online 15 February & through direct field interviews with 35 watercress farmers. \\
\hline 2020 & $\begin{array}{l}\text { The method in this study is quantitative. The result shows } \\
\text { that the land area and the cost of production facilitie have a }\end{array}$ \\
\hline $\begin{array}{l}\text { Keyword: Results of watercress } \\
\text { production; land area; } \\
\text { production cost; labor }\end{array}$ & $\begin{array}{l}\text { positive and significant effect on the production of watercress. } \\
\text { While labor has a significant negative effect on the production } \\
\text { of watercress. }\end{array}$ \\
\hline
\end{tabular}

JEL Classification

Q12

\section{PENDAHULUAN}

Salah satu subsektor pertanian yang memberikan kontribusi signifikan terhadap PDB nasional adalah holtikultura. (Analisis PDB Sektor Pertanian, 2015) Tanaman holtikultura memfokuskan pada budidaya tanaman buah, tanaman bunga, tanaman sayuran, tanaman obat agar mampu mencukupi kebutuhan pasar dalam negeri termasuk argroindustri. Salah satu tanaman agroindustri dan hidrofit yang memiliki peluang pasar yang cukup besar adalah selada air. (Lakamisi, 2010)

Selada air (Nasturtium Officinale) adalah tumbuhan menahun yang cepat tumbuh dan memiliki sifat akuatik atau semi akuatik yang berasal dari Eropa dan Asia. Tanaman ini adalah salah satu dari sayuran daun tertua yang dikonsumsi manusia. Selada air sangat mudah tumbuh dan sering ditemukan tumbuh liar di aliran sungai kecil, rawa, kolam atau bagian danau yang dangkal. Selada air memerlukan iklim sejuk untuk tumbuh, meskipun dapat tumbuh di dataran tinggi atau rendah, tetapi pertumbuhan yang paling baik dicapai di dataran tinggi yang beriklim lembab. (Nana, Kune \& Hutapea, 2018).

Kecamatan Poncokusumo merupakan salah satu wilayah diantara 33 Kecamatan yang saat ini terdapat di Kabupaten Malang, yang secara geografis merupakan kawasan dengan kondisi lahan berupa hamparan lahan yang cenderung berbukit-bukit karena berada di sebelah barat lereng gunung semeru yang sebagian besar merupakan lahan produktif berada pada ketinggian antara 600 sampai dengan 1200 meter diatas permukaan laut dengan curah hujan rata-rata antara $2300 \mathrm{~mm}$ samapai dengan $2500 \mathrm{~mm}$ per tahun dan suhu rata-rata 21,7 derajat celcius, sehingga memiliki peluang untuk mengembangkan usaha pertanian. Dengan kondisi geografis tersebut Kecamatan Poncokusumo serta ketersediaan lahan yang menjadikan usaha 
pertanian bisa diarahkan pada pengembangan tanaman sayuran. Mayoritas masyarakat di Kecamatan Poncokusumo berusahatani sayur mayur untuk memenuhi kebutuhan sehari - hari. (BPS, Kabupaten Malang, 2017) Pada saat musim kemarau pun, para petani masih dapat menanam selada air, dan sangat menguntungkan bagi mereka. Pemilihan sayur ini karena kualitas air sungai sangat jernih sehingga kualitas sayur lebih bagus dan banyak dicari. Apalagi masa panennya juga lebih cepat dan itu sangat menguntungkan, maka dari itu banyak petani yang konsisten menanam selada air.

Salah satunya adalah Desa Wringin Anom mempunyai potensi yang cocok untuk menanam tanaman selada air, baik dari faktor tanah, pengairan maupun cuacanya yang mendukung untuk kegiatan usahatani selada air. Desa tersebut memiliki komoditas unggulan yakni selada air yang telah di produksi dan masih dikembangkan sampai saat ini.

Tabel 1. Data luas dan jumlah produksi dalam 3 tahun terakhir Di Desa Wringin Anom

\begin{tabular}{lllll}
\hline No & Satuan & 2013 & 2014 & 2015 \\
\hline 1 & Luas (Ha) & 4.139 & 4.578 & 4.893 \\
\hline 2 & Jumlah & 1.269 & 1.652 & 1.803 \\
& Produksi (Ton) & & & \\
\hline
\end{tabular}

Sumber : BPS Kabupaten Malang 2015

Dapat dilihat dari table diatas bahwa selada air yang diproduksi bertambah dari tahun ke tahun. Selada air yang diproduksi oleh Desa Wringin Anom telah memberikan banyak kontribusi yang nyata bagi petani. Selada air sendiri memiliki nilai ekonomis yang dapat dilihat dari tingkat kesejahteraan petaninya yang relatif tinggi. Hasil panen selada air yang segar telah banyak dipasok ke kota - kota besar di Jawa Timur. Selain pasar tradisional, selada air juga telah merambah ke pasar modern.

Input atau faktor produksi sektor pertanian adalah semua pengorbanan yang diberikan untuk tanaman selada air agar mampu tumbuh dengan baik dan menghasilkan secara optimal. Faktor produksi sangat menentukan besar kecilnya produk yang diperoleh. Dari berbagai penelitian menunjukkan bahwa faktor luas lahan dan biaya produksi, tenaga kerja dan aspek manajemen adalah faktor produksi terpenting diantara faktor produksi yang lain. (Kalauw, 2015)

Hasil penelitian yang dilakukan oleh Cholis (2017) adalah, Luas lahan, biaya tenaga kerja dan biaya pupuk berpengaruh positif signifikan terhadap produksi padi pada 33 kecamatan di kabupaten Malang.

Hasil penelitian yang dilakukan oleh Fika F (2016) ini menunjukan bahwa tenaga kerja dan luas lahan berpengaruh positif dan signifikan terhadap produksi sektor pertanian di Jawa Timur.

Penelitian yang dilakukan Mufriantie (2014) memiliki hasil yaitu secara keseluruhan (serempak) variabel yang diamati berpengaruh signifikan terhadap produksi, sedangkan secara parsial variabel luas lahan, pupuk urea , pupuk kandang dan tenaga kerja tidak berpengaruh signifikan terhadap produksi dan variabel benih berpengaruh signifikan terhadap produksi bayam. 
Hasil penelitian yang dilakukan oleh Saragih (2013) adalah, secara parsial pola tanam dan pupuk organik berpengaruh signifikan terhadap produktivitas sayur mayur, sedangkan faktor yang lain tidak berpengaruh signifikan, diantara lain pupuk kimia, tenaga kerja dan pestisida.

Hasil penelitian yang dilakukan oleh Achadin (2017) adalah, luas lahan dan tenaga kerja berpengaruh signifikan terhadap produksi tebu pada perkebunan rakyat di Provinsi Jawa Timur tahun 2011 - 2015.

Hasil penelitian yang dilakukan oleh Manurung (2019) adalah, luas areal, umur tanaman, tenaga kerja, dan pupuk signifikan mempengaruhi variabel bebas pada tingkat signifikan 99\%. Variabel luas areal, tenaga kerja, dan pupuk secara positif mempengaruhi variabel terikat atau memperngaruhi meningkatkan produksi TBS kelapa sawit dan variabel umur tanaman berpengaruh negatif terhadap produksi TBS kelapa sawit.

Penelitian ini diambil karena memang potensi selada air di Kecamatan Poncokusumo sangat besar, dari tekstur tanah, iklim dan air yang sangat mendukung untuk menanam selada air. Selain itu selada air juga tumbuh dengan sangat cepat, dan dapat dipanen lebih dari satu kali dalam satu kali tanam. Kini para petani yang mayoritas menanam selada air yang secara otomatis bersaing satu sama lain, apalagi harga jual selada air kepada tengkulak yang murah membuat petani kesulitan dan sedangkan biaya produksinya yang semakin tinggi.

Pengambilan data untuk di jadikan perbandingan karena sama-sama menganalisis faktor - faktor yang Mempengaruhi tingkat produksi. Namun yang membedakan penelitian sebelumnya dengan penelitian sekarang yaitu pada penelitian sekarang memfokuskan pada variabel luas lahan, biaya produksi dan tenaga kerja. Perbedaan lainnya juga terletak di wilayah dan tahun penelitian yang berbeda.

Tujuan dari penelitian ini untuk mengetahui apakah faktor luas lahan, biaya produksi dan tenaga kerja berpengaruh positif terhadap hasil produksi petani.

\section{METODE PENELITIAN}

Objek penelitian ini adalah produksi selada air di Desa Wringin Anom Kecamatan Poncokusumo, Kabupaten Malang. Jenis data penelitian ini dapat dibedakan dalam dua jenis yaitu data kualitatif (yang berbentuk katakata/kalimat) dan data kuantitatif (yang berbentuk angka). Berdasarkan sumbernya, data penelitian ini dapat dikelompokkan dalam dua jenis yaitu data primer dan data sekunder dan Populasi dari penelitian ini adalah petani selada air di Desa Wringin Anom, sebanyak 50 petani selada air. Dengan pengambilan sampelnya dengan cara purposive sebanyak 35 petani selada air sampel dipilih secara sengaja dengan meminta rekomendasi dari ketua Kelompok Tani Harapan Jaya.Tehnik pengumpulan data ini melalui wawancara, kuesioner dan observasi.

\section{Metode analisis data}

Penelitian ini menggunakan Analisis Regresi Linear Berganda, pengujian hipotesis dan uji asumsi klasik. Analisis regresi linier berganda yaitu untuk mengetahui pengaruh antara variabel independen terhadap 
Analisis Faktor - Faktor Yang Mempengaruhi Tingkat Produksi Selada Air

(Studi Desa Wringin Anom Kecamatan Poncokusumo Kabupaten malang)

variabel dependen dengan metode kuadrat kecil (Gujarati, 2009). Diketahui model fungsi produktivitas tenaga kerja sebagai berikut :

$$
\mathrm{Y}=\beta_{1} \text { Alf }+\beta_{2} \mathrm{Aml}+\beta_{3} \mathrm{Amn}+\mu
$$

Dimana :

Y $\quad=$ Produksi Petani Selada Air

Alf = Luas Lahan

Aml = Biaya Produksi

Amn = Tenaga Kerja

\section{Uji Asumsi klasik}

Uji normalitas bertujuan untuk mengetahui apakah dalam suatu model regresi, variabel bebas, variabel terikat atau keduanya mempunyai distribusi normal atau tidak. Model regresi yang baik adalah berdistribusi data normal.

Uji Multikolinearitas atau Kolinearitas Ganda (Multicollinearity) adalah untuk menentukan dan mengetahui ada tidaknya hubungan dua atau lebih variabel yang saling berkaitan dalam suatu model.multikolinearitas terjadi apabila terdapat nilai koefisien korelasi variabel diluar batas-batas penerimaan, dan sebaliknya apabila nilai-nilai koefisien korelasi terletak di dalam batas-batas peneriman maka tidak akan terjadi multikolinearitas. (Ghazali, 2013).

Uji Heteroledastisitas digunakan untuk mengetahui ada atau tidaknya suatu penyimpangan asumsi klasik heterokedastisitas yaitu terdapatnya ketidaksamaan varian dari residual pada sebuah model regresi. Untuk melakukan sebuah pengujian diperlukan beberapa sebuah metode. (Gujarati, 2007).

\section{Uji Hipotesis}

Uji-t yaitu uji untuk mengetahui apakah pengaruh masing masing variabel bebas terhadap variabel terkait bermakna atau tidak.pengujian dilakukan dengan menlakukan perbandingan antar nilai $t$ hitung masing masing variabel bebas dengan nilai t tabel dengan derajat kesalahan $5 \%$ dalam arti $(0,05)$. (Gujarati, 2007)

Uji-F mengetahui apakah varibel bebasnya secara bersama sama mempunyai pengaruh terhadap variabel terkait Pengujian dilakukan membandingkan nilai Fhitung dengan Ftabel pada derajat kesalahan 5\% dalam arti $(\alpha=0.05)$. Apabila nilai Fhitung $\geq$ dari nilai Ftabel, maka variabel bebasnya bermakna terhadap variabel terkait atau hipotesis pertama sehingga dapat diterima. (Gujarati, 2007)

\section{Koefisien Determinasi $\left(\mathbf{R}^{2}\right)$}

Koefisien determinasi $\left(\mathrm{R}^{2}\right)$ pada dasarnya untuk mengukur seberapa jauh kemampuan model dalam menjelaskan variabel dependen. Nilai koefisien determinasi adalah antara 0 dan $1\left(0 \leq \mathrm{R}^{2} \leq 1\right)$. Nilai $\mathrm{R}^{2}$ yang kecil berarti kemampuan variabel-variabel independen dalam menjelaskan variabel dependen sangat terbatas. Nilai yang mendekati satu berarti variabel-variabel independen memberikan hampir semua informasi yang dibutuhkan untuk memprediksi variabel dependen (Ghozali, 2006). 


\section{HASIL DAN PEMBAHASAN}

Poncokusomo adalah merupakan kecamatan yang masuk dalam wilayah Kabupaten Malang. Kecamatan ini terdiri dari 17 desa, yaitu Dawuhan, Karanganyar, Sumberejo, Jambesari, Pandansari, Ngebruk, Ngadireso, Pajaran, Wonorejo, Argosuko, Karangnongko, Wonomulyo, Belung, Wringinanom, Poncokusumo, Gubugklakah dan Desa Ngadas. Luas Kecamatan Poncokusumo adalah $20.632 \mathrm{Ha}$. Sebagian besar penduduk Poncokusumo bekerja sebagai petani. Kecamatan Poncokusumo mempunyai 17 desa dan jumlah penduduknya sebanyak 93.153 jiwa (Laki-laki 49.401 jiwa, Perempuan 49.752 jiwa).

Kecamatan ini berada di ketinggian 1200-1400 Mdpl dan terletak di kaki Gunung Semeru. Kecamatan Poncokusumo sendiri memiliki hasil produksi seperti apel, jeruk, belimbing, kelengkeng mutiara, sayur mayur, bunga irisan yang tumbuh subur di daerah tersebut. Berikut merupakan data responden mengenai luas lahan pada sektor perkebunan selada air di Kecamatan Poncokusumo.

Tabel 2. Tanggapan Responden Mengenai Luas Lahan

\begin{tabular}{cccc}
\hline No & Luas Lahan & Responden & $\begin{array}{c}\text { Frekuensi } \\
\%\end{array}$ \\
\hline 1. & $<500 M^{2}$ & 7 & 20 \\
2. & $600 M^{2}-1000 M^{2}$ & 9 & 26 \\
3. & $15000 M^{2}-2000 M^{2}$ & 1 & 3 \\
4. & $2500 M^{2}-3000 M^{2}$ & 10 & 28 \\
5. & $>3500 M^{2}$ & 8 & 23 \\
& Total & 35 & 100 \\
\hline
\end{tabular}

Sumber : Data Primer (diolah) 2019

Berdasarkan Tabel 2 hasil dari kuesioner dengan 35 responden yang menyatakan luas lahan dengan jumlah $<500 \mathrm{M}^{\wedge} 2$ adalah sebanyak 7 responden dengan persentase $20 \%$, yang menyatakan luas lahan dengan jumlah $600 \mathrm{M}^{\wedge} 2-1000 \mathrm{M}^{\wedge} 2$ adalah sebanyak 9 responden dengan persentase $26 \%$, yang menyatakan luas lahan dengan jumlah $1500 \mathrm{M}^{\wedge} 2-2000 \mathrm{M}^{\wedge} 2$ sebanyak 1 responden dengn persentase 3\%, yang menyatakan luas lahan dengan jumlah $2500 \mathrm{M}^{\wedge} 2-3000 \mathrm{M}^{\wedge} 2$ sebanyak 10 responden dengan persentase $28 \%$ yang menyatakan luas lahan dengan jumlah $>3500 \mathrm{M}^{\wedge} 2$ sebanyak 8 responden dengan persentase 23\% Frekuensi terbanyak berada pada luas lahan $>2500 \mathrm{M}^{\wedge} 2-3000 \mathrm{M}^{\wedge} 2$ dengan responden yang menjawab sebanyak 10 responden dengan frekuensi $28 \%$ dan frekuensi terendah berada pada luas lahan15000 $\mathrm{M}^{\wedge} 2$ - 2000M^2 dengan responden sebanyak 1 responden dengan frekuensi $3 \%$. Jadi rata - rata luas lahan di Desa Wringin Anom adalah $2.160 \mathrm{M}^{\wedge} 2$

Berikut merupakan data responden mengenai jumlah tenaga kerja pada sektor perkebunan selada air di Kecamatan Poncokusumo. Banyak para petani atau pemilik lahan lebih memilih menggarap lahannya sendiri, untuk menghemat biaya dan para pemilik lahan tersebut akan menggunakan tenaga 
Analisis Faktor - Faktor Yang Mempengaruhi Tingkat Produksi Selada Air (Studi Desa Wringin Anom Kecamatan Poncokusumo Kabupaten malang)

kerja pada saat panen, para tenaga kerja akan dibayar sesuai dengan banyaknya mereka memanen yaitu Rp. 1000/ikat.

Tabel 3. Penggunaan Tenaga Kerja Dalam Produksi

\begin{tabular}{cccc} 
No & $\begin{array}{c}\text { Jumlah Tenaga } \\
\text { Kerja }\end{array}$ & $\begin{array}{c}\text { Pemilik } \\
\text { Lahan }\end{array}$ & Frekuensi \\
\hline 1. & 1 & 4 & 11 \\
2. & 2 & 21 & 60 \\
3. & 3 & 8 & 23 \\
4. & 4 & 2 & 6 \\
& Total & 35 & 100 \\
\hline
\end{tabular}

Sumber : data primer (diolah) 2019

Berdasarkan Tabel 3 hasil dari kuesioner dengan 35 responden yang menyatakan jumlah tenaga kerja dengan jumlah 1 orang sebanyak 4 responden dengan persentase $11 \%$, yang menyatakan jumlah tenaga kerja dengan jumlah 2 orang sebanyak 21 responden dengan persentase $60 \%$, yang menyatakan jumlah tenaga kerja dengan jumlah 3 orang sebanyak 8 responden dengan persentase 23\%, yang menyatakan jumlah tenaga kerja dengan jumlah 4 orang sebanyak 2 responden dengan persentase $6 \%$. Frekuensi terbanyak berada pada jumlah tenaga kerja 2 orang sebanyak 21 responden dengan frekuensi $60 \%$ dan frekuensi terendah yaitu tenaga kerja 4 orang dengan responden sebanyak 2 orang dengan persentase $6 \%$. Jadi rata rata penggunaan tenaga kerja yang digunakan adalah 2 orang.

Berikut merupakan data responden mengenai biaya sarana produksi pada sektor perkebunan selada air di Kecamatan Poncokusumo. Biaya biaya yang dikeluarkan oleh petani diantara lain adalah bibit, obat dan biaya transportasi.

Tabel 4. Tanggapan Responden Mengenai Biaya Sarana produksi

\begin{tabular}{cccc}
\hline No & Biaya Produksi & Responden & $\begin{array}{c}\text { Frekuensi } \\
\text { \% }\end{array}$ \\
\hline 1. & $<$ Rp 950.000 & 9 & 26 \\
2. & Rp 1.000.000 - Rp 2.500.000 & 13 & 37 \\
3. & Rp 2.600.000 - Rp 3.700.000 & 7 & 20 \\
4. & $>$ Rp 4.000.000 & 6 & 17 \\
\multicolumn{2}{c}{ Total } & 35 & 100 \\
\hline
\end{tabular}

Sumber : Data Primer (diolah) 2019

Berdasarkan Tabel 4 hasil dari kuesioner dengan 35 responden yang menyatakan jumlah biaya sarana produksi dengan jumlah $<\mathrm{Rp} 950.000$ sebanyak 9 responden dengan persentase 26\%, yang menyatakan jumlah biaya sarana produksi dengan jumlah $\mathrm{Rp} 1.000 .000$ - Rp 2.500 .000 sebanyak 13 responden dengan persentase $37 \%$, yang menyatakan jumlah biaya sarana produksi dengan jumlah $>\mathrm{Rp} 2.600 .000$ - Rp 3.700 .000 sebanyak 7 responden dengan persentase $20 \%$, yang menyatakan jumlah biaya sarana produksi dengan jumlah $>\operatorname{Rp} 4.000 .000$ sebanyak 6 responden dengan persentase $17 \%$. 
Frekuensi terbanyak berada pada jumlah biaya sarana produksi sebesar $\mathrm{Rp} 2.000 .000$ - Rp 2.500.000 dengan responden sebanyak 19 responden dengan persentase $54 \%$ dan frekuensi terendah pada jumlah biaya sarana produksi Rp 1.000 .000 sebanyak 5 respondendengan persentase $14 \%$. Jadi rata - rata biaya produksi yang dikeluarkan oleh petani adalah Rp. 2.217.600.

Berikut merupakan data responden mengenai hasil produksi pada sektor perkebunan selada air di Kecamatan Poncokusumo. Hasil produksi yang dihitung adalah dalam jumlah ikat dan perikatnya dijual ke tengkulak dengan harga Rp.9000.

Tabel 5. Tanggapan Responden Mengenai Hasil Produksi

\begin{tabular}{cccc} 
No. & Hasil Produksi (Ikat) & Responden & $\begin{array}{c}\text { Frekuensi } \\
\text { \% }\end{array}$ \\
\hline 1. & $<100$ & 3 & 8 \\
2. & $150-200$ & 4 & 11 \\
3. & $300-500$ & 8 & 23 \\
4. & $550-800$ & 10 & 29 \\
5. & $>1000$ & 10 & 29 \\
& Total & 35 & 100 \\
\hline
\end{tabular}

Sumber : Data Primer (diolah) 2019

Berdasarkan Tabel 5 hasil dari kuesioner dengan 35 responden yang menyatakan hasil produksi selada air sebesar $<100$ ikat adalah sebanyak 3 responden dengan persentase $8 \%$, yang menyatakan hasil produksi sebesar 150 ikat - 200 ikat adalah sebanyak 4 responden dengan persentase sebanyak $11 \%$, yang menyatakan hasil produksi sebesar 300 ikat - 500 ikat sebanyak 8 responden dengan persentase $23 \%$, yang menyatakan hasil produksi sebesar 550 ikat - 800 ikat sebanyak 10 responden dengan persentase $29 \%$, yang menyatakan hasil produksi sebesar $>1000$ ikat sebanyak 10 responden dengan persentase $29 \%$.

Jumlah hasil produksi terbesar adalah kisaran 550 ikat - 800 ikat dan $>1.000$ ikat dengan masing - masing responden sebanyak 10 responden dan persentase 29\%, sedangkan produksi terendah $<100$ ikat sebanyak 3 responden dengan presentase $8 \%$.

Tabel 6. Hasil Analisis Regresi Linear Berganda

\begin{tabular}{|c|c|c|c|c|c|c|}
\hline \multicolumn{7}{|c|}{ Coefficients $^{\mathrm{a}}$} \\
\hline & & $\begin{array}{l}\text { Unstand } \\
\text { Coeffic }\end{array}$ & $\begin{array}{l}\text { ardized } \\
\text { cients }\end{array}$ & $\begin{array}{c}\text { Standardized } \\
\text { Coefficients }\end{array}$ & & \\
\hline \multicolumn{2}{|c|}{ Model } & $\mathrm{B}$ & Std. Error & Beta & $\mathrm{T}$ & Sig. \\
\hline \multirow[t]{4}{*}{1} & (Constant) & 33.006 & 57.252 & & .576 & .568 \\
\hline & Luas Lahan & .177 & .035 & .541 & 5.111 & .000 \\
\hline & $\begin{array}{l}\text { Biaya } \\
\text { Produksi }\end{array}$ & .000 & .000 & .477 & 4.677 & .000 \\
\hline & Tenaga Kerja & -27.131 & 27.215 & -.036 & -.997 & .327 \\
\hline
\end{tabular}

a. Dependent Variable: Hasil Produksi

Sumber : Data Primer Diolah 2019 
Dari hasil perhitungan olah data dengan program spss menunjukkan bahwa F-hitung sebesar 384.849 dan besar nilai F-tabel sebesar 2,90 sehingga dari perhitungan di atas dapat diketahui bahwa $\mathrm{H} 0$ ditolak dan $\mathrm{H} 1$ diterima. Hal ini berarti bahwa variabel luas lahan, biaya produksi dan tenaga kerja secara bersama-sama mempunyai pengaruh signifikan terhadap variabel hasil produksi.

Koefisien determinasi (R2) sebesar 97\% menunjukan bahwa produksi selada air yang dipengaruhi oleh variabel bebas yakni luas lahan, biaya produksi dan Tenaga Kerja. sedang sisanya 3\% dipengaruhi oleh variabel lain yang tidak dimasukan dalam model ini misalnya iklim, kesuburan, dan lainlain.

Dari tabel diatas menujukkan bahwa hasil uji t dari 3 variabel yang diamati yaitu luas lahan dan biaya produksi berpengaruh signifikan terhadap hasil produksi selada air dengan t hitung sebesar 5,111 dan 4,677, dimana $t$ hitung $>$ t tabel $(1,6895)$, sedangkan tenaga kerja tidak berpengaruh signifikan terhadap hasil produksi dengan $t$ hitung $-0,997$, dimana $<\mathrm{t}$ tabel $(1,6895)$.

1. Pengaruh Luas Lahan Terhadap Hasil Produksi

Berdasarkan hasil analisis yang dilakukan pada penelitian ini, dapat dijelaskan bahwa luas lahan berpengaruh positif signifikan secara parsial. Terhadap produksi selada air. Hal ini menunjukkan adanya hubungan searah antara luas lahan dengan hasil produksi selada air, sehingga semakin luas lahan yang digunakan maka semakin banyak pula hasil produksi yang dihasilkan. Hasil ini didukung oleh penelitian yang dilakukan oleh Cholis (2017), bahwa luas lahan mempunyai pengaruh positif dan signifikan terhadap hasil produksi selada air.

2. Pengaruh Biaya Produksi Terhadap Hasil Produksi

Berdasarkan hasil analisis yang dilakukan penelitian ini, dapat dijelaskan bahwa biaya produksi berpengaruh positif terhadap hasil produksi selada air. Hal ini sesuai dengan penelitian yang dilakukan oleh Cholis (2017), bahwa biaya produksi berpengaruh positif terhadap hasil produksi selada air karena biaya sarana produksi yang dikeluarkan untuk kebutuhan petani selada air juga berpengaruh terhadap hasil produksi, karena jika kebutuhan petani selada air yang dikeluarkan banyak maka hasil produksi yang dihasilkan juga banyak. Hasil tersebut menunjukkan bahwa biaya sarana produksi berpengaruh positif dan signifikan terhadap hasil produksi selada air. Biaya sarana produksi setiap petani berbeda-beda tergantung dari luas lahan yang mereka miliki. Jika luas lahan banyak dan kebutuhan perawatan banyak, maka biaya sarana produksi yang dikeluarkan juga banyak

3. Pengaruh Tenaga Kerja Terhadap Hasil Produksi

Berdasarkan hasil analisis yang dilakukan penelitian ini, dapat dijelaskan bahwa tenaga kerja tidak berpengaruh terhadap hasil produksi selada air. Hal ini sesuai dengan penelitian yang dilakukan oleh Saragih (2013), bahwa tenaga kerja tidak berpengaruh terhadap hasil produksi selada air, karena penggunaan tenaga kerja merupakan faktor yang harus dipenuhi untuk kelangsungan kegiatan usaha tani selada air. Keterlibatan tenaga kerja dimulai dari saat pengelolaan lahan hingga panen. Tenaga 
kerja tentunya harus cermat dan benar - benar diperhitungkan. Penggunaan tenaga kerja yang berlebihan akan menaikkan biaya produksi sehingga biaya produksi yang dikeluarkan akan meningkat dan berpotensi akan mendatangkan kerugian.

\section{KESIMPULAN}

Berdasarkan hasil penelitian dan analisis data, faktor luas lahan, biaya produksi dan tenaga kerja secara bersama - sama mempengaruhi hasil produksi selada air di Desa Wringin Anom, Kecamatan Poncokusumo.

Luas lahan berpengaruh positif dan signifikan terhadap hasil produksi selada air. Karena semakin banyak dan luas lahan yang digarap, maka dapat meningkatkan hasil produksi. Biaya produksi berpengaruh positif dan signifikan terhadap hasil produksi selada air. Karena semakin banyak biaya produksi yang dikeluarkan maka jumlah hasil produksi akan meningkat. Tenaga kerja berpengaruh negative dan signifikan.

Bagi pemerintah diharapkan untuk lebih memperhatikan petani selada air di Kecamatan Poncokusumo dan membantu dalam memudahkan memasarkan selada air ke daerah lain karena potensi selada air yang bagus dan kontribusinya yang cukup besa

\section{DAFTAR PUSTAKA}

Lakamisi, H. (2010). Analisis Usahatani Brocolli. Agrikan UMMUTernate Vol. 3 Edisi 2 Oktober.

Nana, Kune \& Hutapea. (2018). Analisis Pendapatan Usahatani Selada Air di Desa Popnam, Kecamatan Noemuti, Kabupaten Timor Tengah Utara. Jurnal Agrimor Vol. 3 No. 1 Januari.

Badan Pusat Statistik. (2017). Kabupaten Malang Dalam Angka 2017. $\begin{array}{llll}\text { Retrieved } & 8 & \text { Agustus } & 2017\end{array}$ https://malangkab.bps.go.id/publication/2017/08/08/6533ec882630b114e5 6ece04/kabupaten-malang-dalam-angka-2017.html

Badan Pusat Statistik. (2015). Kabupaten Malang Dalam Angka 2015.

$\begin{array}{llll}\text { Retrieved } & 27 & \text { November } & 2015\end{array}$
https://malangkab.bps.go.id/publication/2015/11/27/ae2c651f526c75c4478 2398/kabupaten-malang-dalam-angka-tahun-2015.html

Kalauw.(2010). Analisis Faktor-Faktor Yang Mempengaruhi Produksi Sayuran Buncis (Phaseolus Vulgaris L) Di Dusun Telaga Kodok Kabupaten Maluku Tengah. Jagrilan Vol. 3 No. 215 Juni.

Cholis. (2017). Analisis Faktor-Faktor Yang Mempengaruhi Produksi Padi Di Kabupaten Malang. Ekonomi Pembangunan.

Fika, F. (2016). Analisis Hasil Produksi Sektor Pertanian di Kabupaten/Kota Provinsi Jawa Timur. Ekonomi Pembangunan . 
Mufriantie. (2016). Analisis Faktor-Faktor Yang Mempengaruhi Pendapatan Petani Ikan Nila Di Kecamatan Seginim Kabupaten Bengkulu Selatan. Agrisep Vol. 17 No. 1 .

Saragih. (2013). Analisis Pendapatan Petani dan Faktor-Faktor Yang Mempengaruhi Produktivitas Sayur Mayur di Kecamatan Purba Kabupaten Simalungun. Agrica Vol. 6 No. 2 Oktober.

Achadin. (2017). Analisis Faktor Yang Mempengaruhi Produksi Tebu Pada Sub Sektor Perkebunan Di Provinsi Jawa Timur Tahun 2011-2015. Ekonomi Pembangunan. Vol. 15 No. 2 Desember.

Manurung. (2019). Analisis Faktor-Faktor yang Mempengaruhi Produksi Tandan Buah Segar Buah (TBS) Kelapa Sawit di Kebun Bangun Bandar, PT. Socfin Indonesia. JEPA Vol. 3 No. 3.

Gujarati. (2009). Basic Econometric 5th Edition. McGraw - Hill Company.

Ghozali, I. (2013). Aplikasi Analisis Multivariate dengan Program IBM SPSS 21 Update PLS Regresi. Semarang: UNDIP. 